\title{
Arab Students Learning Arabic as Their First Language and Jewish Students Learning Arabic as Their Second Language
}

\author{
Salim Abu-Rabia1, Khalid Tarabeh1, Haneen Wattad ${ }^{2}$ \\ ${ }^{1}$ Faculty of Education, University of Haifa, Haifa, Israel \\ ${ }^{2} \mathrm{Al}$ Qasemi Academic College, Baqa, Israel \\ Email: salimar@edu.haifa.ac.il
}

How to cite this paper: Abu-Rabia, S., Tarabeh, K., \& Wattad, H. (2022). Arab Students Learning Arabic as Their First Language and Jewish Students Learning Arabic as Their Second Language. Creative Education, 13, 393-421.

https://doi.org/10.4236/ce.2022.132023

Received: December 14, 2021

Accepted: February 11, 2022

Published: February 14, 2022

Copyright $\odot 2022$ by author(s) and Scientific Research Publishing Inc. This work is licensed under the Creative Commons Attribution International License (CC BY 4.0).

http://creativecommons.org/licenses/by/4.0/

\section{(c) (i) Open Access}

\begin{abstract}
The goal of the present study is to investigate how Arabic is acquired among Jewish pupils who learn it as a second language (SL) in Israel and how Arabs acquire the Arabic language as their first language (L1). Both groups study Arab together in bilingual schools. This topic has not been investigated in bilingual schools in Israel. Such a study of this topic may clarify the developmental process of Arabic among Arab and Jewish students compared with their peers in regular monolingual schools. The research population comprised of random samples of 30 Arabic pupils and 30 Jewish pupils from each grade level: An overall sample consisted of 180 participants from bilingual schools. Similar sample was sampled from regular monolingual Arab and Jewish schools. The statistical analysis revealed no significant differences between pupils' groups in the $3^{\text {rd }}$ grade, particularly about Arab pupils learning in bilingual schools and Arab pupils learning in monolingual schools. However, the result of the higher grades revealed that bilingual pupils, Arabs and Jews, received better abilities regarding Arabic than their Arab peers learning in monolingual schools, which supports the idea of the advantages in providing bilingual education from an early age for both Jews and Arabs in Israel.
\end{abstract}

\section{Keywords}

Bilingual Education, Metalinguistic Awareness, Arabic, Bilingual Schools

\section{Introduction}

This study investigates the learning of Arabic by Jews and Arabs learning together in bilingual schools. The question here is interesting due to the problematic Israeli Arab social context, such a context does not permit natural learning 
atmosphere. How do their Arabic language skills develop, especially among Jewish pupils that Arabic is not their mother tongue?

Cummins (1979) suggests that cognitive academic linguist ability is transferred from one language to another, which means that high ability in the first language (L1) predicts high ability in the second language, and vice versa (Da Fontoura \& Siegel, 1995). Furthermore, studies support the claim that acquisition of reading and writing ability in SL would be affected by orthographic similarity and difference measure between the L1 and the second (Abu-Rabia, 1997, 2001).

Therefore, the aim of this study is to investigate how Arabic as a language of conflict is reflected among Jewish pupils who learn a second language, which is not their mother tang. This subject has not yet been investigated in bilingual schools in Israel. A study of this subject will shed light on the developmental process of Arabic among Arab and Jewish students compared with their peers in monolingual schools.

Bilingual education offers an alternative education strategy to the existing educational reality in both activity and contents level. To date, there are four bilingual schools in Israel. The first bilingual school has been established in Neve-Shalom in 1984, and the other three were set up in the last decade by "Hand in Hand" - the association for bilingual education in Israel. The first of these three is in Jerusalem; it was set up in a vacant wing of a local public high school, thriving to anchor respect and appreciation to the different traditions represented in it.

Studies performed within the Jewish population in Israel revealed that this population does not merit high status to the Arabic language and that stances regarding teaching it in Jewish schools are not positive (Ben-Rafael \& Brosh, 1991). Furthermore, Jewish people in Israel tend to possess stereotype negative perceptions regarding the Arabic language, and highly positive stance regarding the Hebrew language. They perceive English as the most important FL, and it is the language preferred as Lingua Franca in the Middle East (Ben-Rafael \& Brosh, 1991).

\section{Literature Review}

This literature review presents some of the main theories of second/FL acquisition.

Cummins (1979) Linguistic Interdependence Hypothesis refers to the dependency between one language to another, meaning, and the passing of linguist skills in one language to another; a process that occurs automatically regardless of orthography type. Intensive exposure to a SL leads to rapid bilingual development without negative influence on the L1. Many studies have investigated the development of bilingual skills and the transfer of skills from one language to another (Geva \& Siegel, 2000) and refer to the above-mentioned hypothesis.

However, the Script Dependent Hypothesis proposes that reading efficiency in the SL is a direct function of the L1 orthography type. Therefore, orthographies' difference plays an important role in the reading process of the second language. 
In addition, this hypothesis claims that reading development in each language relates to the orthographic traits of that language (Abu-Rabia, Share, \& Mansour, 2003).

Many studies revealed that when the orthography of the L1 differs from that of the second language, it has a negative effect on word decoding. Orthographic skills predict reading abilities in the language that they are measured and do not predict the passing over of reading ability to the second language. Therefore, when the two orthographies differ, to ease and accelerate the learning process of the second language, it is important to adjust the learning strategy of the SL to the nature of the specific characteristics of the L1 (Lefranois \& Armand, 2003).

Similarly, the Orthographic Depth Hypothesis suggests that readers adjust their reading strategy to the orthographic characteristics of the language (Frost, 1994; Katz \& Frost, 1992). Shallow orthographies have high-level consistency and the readers tend to rely on the "sub-lexical" phonological track, where in deep orthographies, there is a low consistency and the readers rely more on the "lexical" orthographic track of identifying the complete word.

In consistent orthographic systems, like in languages such as: Greek, German, Spanish, Italian, Finish and Serbo-Croatia, the reader relies on the phonologic decoding strategy, since the connection between grapheme and phoneme is direct, while in non-consistent orthographies, like in the English language, the connection between grapheme and phoneme is not always direct (Frost, 1994; Katz \& Frost, 1992).

Additionally, Sparks and Ganschow (1993) and Sparks (1995) suggest the Linguistic Coding Difference Hypothesis; skill in the L1 is used as a basis to the leaning of the second language (L2) and FL. The L1 skills, including: phonology, orthography, syntax and semantics, will be reflected in other languages the child acquires. Difficulties in the linguist code (especially the phonologic, orthographic, syntactical and semantic), which are the basis for individual differences, will be passed over in learning FL.

Furthermore, Ziegler and Goswami (2005) suggested the Psycholinguistic Grain Size Theory: The dramatic difference in reading speed and precision relates to orthography that reflects essential differences in phonological processing characteristics and reading strategies. In languages characterized by sealed orthographies, the reader is forced to cope with the lack of consistency problem, since orthographic units in the given language have more than a single pronunciation option, and some of the phonological units have many spelling possibilities.

These theories are important in order to explain reading and language acquisition in different writing systems and reading stages in general (Abu-Rabia \& Taha, 2013). Their relevancy to the data of this study will be discussed in the discussion section.

\section{The reading process}

Reading is decoding and comprehension of the written language-a process beginning in visual simulation and concludes with comprehension of the idea 
the writer wants to pass on (Rayner \& Pollatsek, 1989). According to Perfetti (2003), reading learning symbolizes the decoding of the spoken language expressed in the written system. This process is reflected by producing meanings from the text regardless of the fact that it is more complex and comprehensive process comprised of many cognitive skills, including: assessment, identification, decoding understanding the deeper strata of the text and more (Jeon \& Yamashita, 2014).

Reading acquisition is not a natural process, it is a complex process requiring the acquisition of several linguistic and meta-linguistic skills. To date, there is no consensus in the research literature regarding the linguistic skills affecting reading acquisition in the L1 that can predict reading ability in second language. Some scholars emphasize the phonological \& morphological awareness and orthographic processing as the basic skills, which are able to predict the ability of reading acquisition in the first and the SL (Jeon \& Yamashita, 2014; Koda, 1992). Following is a brief survey of the linguistic skills examined by the current study as predictive factors for reading ability in Arabic and Hebrew languages.

\section{Phonological awareness}

Phonological awareness is a linguistic skill relating to the identification and operative ability of spoken words with the ability to analyze their internal phonologic structure, like phonemes, syllables and rhymes (Gillon, 2002; Goswami \& Bryant, 1990; Mann, 1991).

Phonologic awareness, providing the initial base for the development of spelling writing and reading, is the ability to decode the connection between the phonemes and the sounds of the letters (Chiappe, Siegel, \& Gottardo, 2002; Chiappe, Siegel, \& Wade-Woolley, 2002).

Phonologic awareness is a cognitive linguistic skill that can pass among languages and it is considered as an important reading predictive in alphabetical languages, not just in the L1, but in the SL as well (Adams, 1994; Chiang \& Rvachew, 2007; De Jong \& Van der Leij, 1999; Mann, 1991; Al-Tamimi \& Rabab’Ah, 2007).

\section{Orthographic knowledge}

The term orthographic knowledge refers to knowledge of the script system of a given language; it is comprised of orthographic clues present in the written words that help to identify the word (Ehri, 1992) or the comprehension of a given text (Wagner \& Barker, 1994).

One of the main parameters of reading acquisition among beginning readers is knowledge of the letters' names (Griffin, Burns, \& Snow, 1998). Knowledge of the letters names often provides access to their sound enabling the beginning reader to acquire primary decoding strategies (Carroll, 2000). Share (1995) adds that knowledge of letters' names can provide proof of primary understanding that words are composed of graphemes that represent phonemes. Furthermore, precision in letter names is an evident for successful reading ability. To process texts in the SL, orthographic knowledge should be automatically mastered and acquired by continuing exposure to written massages. Such acquisition will con- 
tribute to reading ability in the SL.

\section{Morphological awareness}

Morphological awareness is the knowledge of the morphological structure of words and the structure's operative ability (Carlisle, 1995; Carlisle \& Stone, 2003). Morphologic awareness includes access to morphemes, which is reflected in the pupil's ability to implement morpheme kno0wledge to identify and create forms of new words of higher morphological complexity and adjust the new structure to a given language (Abu-Rabia, 2001; Ravid, 2001).

Studies that examined the first stages of reading acquisition found that young pupils show basic understanding of the morphological information composing the word (Carlisle, 1995; Champion, 1997).

This is how, morphological awareness of the spoken language contributes to the reading development of the pupil (Deacon \& Kirby, 2004) according to Carlisle \& Fleming (2003) and other scholars, morphologic awareness has an important role in the enrichment of the pupil's vocabulary. Other studies proved that morphological awareness affects reading comprehension and spelling ability (Casalis \& Louis-Alexander, 2000; Deacon \& Kirby, 2004; Kieffer \& Lesaux, 2008; Abu-Rabia, 2001; Ravid, 2001).

\section{Syntactic awareness}

Syntax awareness helps the reader to learn the semantic role of each word in the sentence, to understand the meaning of the sentences and the context of the concepts in the sentence (Just \& Carpenter, 1987). Durgunoglu (2002) claims that syntax awareness control requires the reader a meta-linguist perception relating to his ability to recognize the internal grammatical structure of the sentences in the language. This is how syntax awareness provides understanding of words integration in larger syntax units, like sentences and phrases (Durgunoglu, 2002; Just \& Carpenter, 1987).

\section{Spelling}

Spelling is a linguistic process in which the pupil learns the connection between sound and graphical symbol, the letter. This is a developmental process occurring simultaneously with reading development, while he learns the orthographic and morphological rules of the language.

Spelling enables the analysis of spelling mistakes and learning from them how the pupils use their language of the spoken language to understand the written language (Ehri, 1992).

Lennox \& Siegel (1993) claim that spelling skills are mediated by two different processes: the phonologic process by which the spellers learn how to represent speaking sounds by letters, and a direct lexical access without phonologic involvement. The main claim of these scholars is that pupils who learn to spell use phonologic and orthographic strategies.

\section{Reading comprehension}

Reading comprehension is the skill referring to understanding of the written text meaning, that is expressed when the reader summarizes information and 
integrates details from the text with previous knowledge (Koda, 2005).

According to Snow \& Sweet (2003), reading comprehension is a complex, multi-dimensional process that requires high cognitive ability. This process is composed of extracting and constructing the reader produces from the text while at the same time integrating these meanings with previous knowledge to build new meanings. Thus, the interaction between the text and the pupils' basic knowledge contributes to the development of reading comprehension (Alderson \& Urquhart, 1988). The aim of reading comprehension is to enable the pupils to read independently by acquiring the tools and skills needed to achieve maximum comprehension of the text, which requires high level of meta-cognitive skills (Durgunoglu, 2002; Goff, Pratt, \& Ong, 2005).

\section{The Arabic Orthographic System}

The specific characteristics of the Arabic orthographic system are considered more complex than those of counterparts in other languages. This alphabetical system is written from right to left and comprises twenty-eight characters that represent consonants, three of which also represent long vowels (Taha, 2013). Short vowels are added as diacritical marks over and under the characters, creating some degree of visual complexity.

Arabic characters vary in form. Each has more than one written form, depending on its position in the word: beginning, middle, or end. The main form of the character, however, is preserved in all cases. Six characters $(j, \dot{j}, 2,1, j)$ connect from the right; each has two forms. The other twenty-two characters may connect from either side; each of them has four forms. Likewise, the characters look much the same because several have the same basic form and are differentiated by the addition of one to three dots over, within, or under them (Abu-Rabia \& Awwad, 2004).

Apart from the varying forms of the characters, vowels are important characteristics of Arabic orthography. There are three long vowels and three short ones. The long vowels are represented by three characters ( $[1-\mathrm{a}-\mathrm{u}-\mathrm{i}])$; the short ones are represented by diacritics over or under the characters. They are chosen in accordance with the meaning of the word and its function in the sentence. In their absence, meaning is understood by context.

Additionally, the presence or absence of short vowels determines orthographic depth (Frost, 1998): when a text is vowelled (accompanied by vowels), the orthography is considered transparent and reading is based mainly on sublexical processes. When the text is unvowelled, the orthography is considered deep because the words are lacking in phonological information, making comprehension dependent on lexical processes. Certain words, however, become homographic (Abu-Rabia, 2001).

Children first learn to read transparent texts; they begin to use deeper orthography in the fourth grade.

Three major characteristics influence the extent of orthographic transparency and contribute to its complexity:

1) The presence of auditory information that relates to pairs of characters that 
have similar phonology and are based on the same part of the vocal system (for example, $[$ [s-ṣ; t-t]: one pronounced at a deep level and the other at a transparent level);

2) The fact that twenty-two of the twenty-eight characters are written in four different ways, depending on their position within the word;

3) The existence of sounds that are written but not pronounced in certain cases, along with others that are pronounced but not written in certain cases (e.g., the character alif in the word "ذهإl" [hāda], which is pronounced "hāda" but written as "hada".

Characteristics such as these abet inconsistency in the grapheme-to-phoneme conversion on which young children rely in the reading process before they master larger morphological units for automatic reading (Saiegh-Haddad \& Henkin-Roitfarb, 2014).

An orthographic system is one's understanding of the writing conventions of the language and of correct and incorrect words. Arabic is a phonological-consonantal sign system that is written by means of a twenty-eight-character set to which diacritics are added. This system is highly complex, written from right to left, and representative of the set of sounds. Therefore, it is strongly phonetic.

As for the morphological system, most Arabic words are built by derivation from roots and combine meaning, represented by the roots, and lexical and syntactic categories, represented by patterns. Even though most roots are composed of three consonants (Abu-Rabia, 2001) that may abet some morphological transformation, these transformations are rarely linear. They tend to fracture the phonological and orthographic identity of the words and weaken their morphological transparency.

Asaad and Eviatar (2014) find it useful to compare the processes of acquiring Arabic and of Hebrew due to patterns of similarity and dissimilarity that exist between the languages. Both languages are Semitic and have root-based morphology in which most words are derived by assimilating a root into a morpho-phonological word pattern.

The orthographies of both languages are A-B-C-D. The characters represent consonants and several long vowels; short vowels, in contrast, are represented by diacritics. Both orthographies allow two possible ways of spelling: with diacritics and without. When diacritics are used, the phonological form of the word is fully represented and the orthography is considered transparent. Non-diacritical spelling, in contrast, has several homographs, the phonological form of words is represented incorrectly, and the orthography is considered deep.

Another conspicuous difference is the visual complexity of the orthographies. Eviatar et al. (2004) showed that it takes longer to identify characters in Arabic than it does in Hebrew or in English.

Abu-Rabia (2002) looked into proficiencies in reading, phonological processing, orthographic processing, performative memory, and spelling in Arabic, Hebrew, and English writing among native speakers of Arabic. They discovered that 
many proficiencies in the first language correlate strongly with spelling in English. They also found unique orthographic challenges in both Arabic and Hebrew. Despite the difference between the two types of writing, each graphic sign has vocalization and the orthography is considered "shallow" or "transparent", i.e., exhibiting a direct relation between grapheme and phoneme. When the opposite situation prevails-when diacritics are not used or full spelling is not used-the orthography is considered "deep" (Abu-Rabia, 2003).

Abu-Rabia (1995) investigated the effect of vowels on reading accuracy among eight eight-year-old readers, some weak and others skilled. They found that vowelling improved their reading accuracy in general and their reading of words in their context particularly.

Children exposed to both forms of Arabic function bilingually because they have a higher level of phonological awareness than do Hebrew-speaking peers. By implication, one may expect them to show progress in gaining reading proficiency. In fact, however, they acquire reading skill in Arabic more slowly than do Hebrew speakers in Hebrew.

In a study conducted among first-graders, the children were given examinations that tested their phonological awareness and their vocabulary with texts tailored to their level. The correlations between the meta-linguistic indicators and reading showed that the level of difficulty in phonological awareness and reading is higher among Arabic-speaking children than among Hebrew-speaking youngsters. One may also see that children read Arabic more slowly and make more mistakes than do children reading Hebrew, even when they demonstrate higher levels of phonological capabilities than monolingual Hebrew speakers do.

\section{Arabic and Its Diglossic Nature}

According to Oweini \& Hazoury (2010), diglossia is "bilingualism"-a situation in which two different forms of speaking, one official and the other vernacular, coexist and are used in different contexts. The two forms are differentiated in contexts, usage, and manner of acquisition (Nevat, Khateb, \& Prior, 2014).

Arabic (al-'Arabiyya) belongs to the Semitic family of languages and has two main forms: a vernacular ('amiya), divided into many geographical dialects (Spoken Arabic Vernacular-SAV), and a literary or standard form (fuṣhâ) (Modern Standard Arabic-MSA). Standard Arabic is not only the written form of Arabic; it is also the main language used in news broadcasts, the media, and religious and political rituals. Considered prestigious and esteemed, it is perceived as a high-level language shared by the intelligentsia throughout the Arab world. SAV, in contrast, with its many variations, is the mother tongue of all Arabic speakers irrespective of their education and is usually acquired before MSA is learned in school. The development of education and the spread of electronic media in the Arab world have set in motion a fascinating encounter between the two forms of the language. In recent decades, an educational spoken Arabic that integrates the abstract literary form of the language with various elements of the vernacular has begun to develop.

The linguistic relationship between SAV and MSA is not straightforward. The 
two languages are far apart in many respects: pronunciation, inflection, syntax, vocabulary, and semantics. These differences create a unique linguistic situation known as diglossia. Diglossia is a relatively uncommon socio-linguistic state in which the written and the spoken languages are so differentiated that one may treat the former almost as a foreign tongue.

Arabic-speaking children are born into this double linguistic context (Ferguson, 1959). They speak the vernacular of their parents, siblings, and peers at home and in their residential surroundings. In school, they are first exposed to MSA in Arabic-language classes. The different code of the standard language is a perceived almost as a foreign tongue and entails literary proficiencies of reading and writing, grammatical knowledge, and linguistic accuracy. As the sole written code, Modern Standard Arabic is also the language of textbooks in all subjects. Outside the school environment, the two linguistic codes maintain a rather stable coexistence, complementing each other in various areas of social functioning. Thus, SAV is used for unofficial quotidian conversational functions, usually oral only. MSA, in contrast, is invoked for writing and official linguistic functions such as religious sermons, speeches, newscasts, and the like (Saiegh-Haddad, 2011).

Leikin et al. (2014) found that the effect of the linguistic distance between MSA and SAV is almost always studied among schoolchildren and less so among preschoolers. This happens for two reasons: First, the formal and direct exposure to MSA coincides with the initial acquisition of reading and writing at the beginning of the child's studies in school. Until then, children are exposed to MSA mainly through stories or watching television programs, but this exposure is weaker both qualitatively and quantitatively. Second, the linguistic distance between the two forms of Arabic has a particularly strong effect on the acquisition of basic reading proficiency.

It is not by chance that children are less successful when they are asked to analyze the pronunciation of literary linguistic structures and compare it with those in vernacular Arabic (Saiegh-Haddad, 2003, 2004). The findings (albeit few) of semantic and metacognitive research confirm these data in most cases, allowing us to hypothesise that children whose mother tongue is Arabic treat MSA much as bilingual children do after they are exposed to both forms of Arabic (Ibrahim \& Eviatar, 2009; Ibrahim \& Aharon-Peretz, 2005). Accordingly, it has been proposed that Arabic diglossia has an adverse effect on the acquisition of basic reading proficiency (Ibrahim, Eviatar, \& Aharon-Peretz, 2007) and, in contrast, a positive effect (like bilingualism) on the development of metalinguistic proficiency (Eviatar \& Ibrahim, 2001).

In the past decade, Saiegh-Haddad \& Geva (2008) have tried to surmount the SAV-MSA gap by providing early exposure to MSA at home and in preschool and by applying a structured and systematic approach in both of these settings. They propose that structured intervention develops awareness of syllables, characters, and identification of sounds, and broadens vocabulary in early childhood. They also observe that SAV has an adverse effect on the development of 
reading. Because children speak SAV until preschool age, they find it difficult to construct phonological representations of MSA words in the early school grades (Saiegh-Haddad et al., 2011; Saiegh-Haddad, 2003, 2004, 2007). Similarly, the cognitive systems of both children and adolescents treat SAV and MSA as separate languages.

Asaad and Eviatar (2014) claim that the diglossic nature of Arabic may impede the process of grapheme-phoneme conversion in form as well. One reason for this is that graphemes may represent phonemes that are unknown in the vernacular of young pupils; another is the linguistic distance between the two forms of Arabic. Due to this distance, children cannot rely on their phonological representations of words in the vernacular, even though the written Arabic orthography is shallow or transparent. Accordingly, to acquire Arabic reading skills they must learn two systems-one linguistic and the other orthographic concurrently.

\section{Early Exposure to MSA and the Acquisition of Arabic}

Although far-reaching exposure to MSA begins when formal education and teaching of reading start in first grade, it is a common error to think that children are exposed only to SAV until then and encounter diglossia only when they reach school. Arabic-speaking children are born into this dual linguistic context and their language ability evolves amid this hybrid linguistic reality. While surrounded mainly by vernacular Arabic, they are exposed to the standard language as well: They hear their parents praying in MSA and see their siblings doing their homework and prepping for exams largely in MSA. They watch television shows and series dubbed in MSA and, if their parents are literate and appreciative of the importance of developing their children's literacy skills, they are told stories in MSA.

In oral discussions that they hold after they read texts, watch television shows, or take an exam, children use SAV, especially in its phonological and morpho-syntactic respects. Just the same, they also insert some words from MSA. A mixed code of this kind, combining the lexicon of standard Arabic with the phonology and the morpho-syntax of the vernacular, is typical of literacy-based speech in Arabic, particularly when words in MSA have no parallel in SAV.

MSA is a predominantly uniform code (Holes, 2004). SAV, in contrast, is largely regional, manifested in dialects that vary among countries, cities, and villages. Despite the large linguistic differences among the dialects, all are structurally related to standard Arabic. However, linguistic analysis of SAV and MSA consistently reveals differences in all aspects of the language, including the phonological, the morpho-syntactic, and the lexical-semantic.

In the linguistic distance that exists between SAV and MSA, a given Arabic linguistic structure may be identified as belonging to one of three categories: SAV only, MSA only, or both together. This typology may be applied to all areas of the language, particularly phonology. That is, Arabic phonemes may be vernacular-only, standard-only, or both. Spoken-only phonemes are used in a specific dialect but do not appear in the MSA phonemic stock. Standard-only pho- 
nemes are those that occur in modern Arabic but not in a given SAV. Both standard-only phonemes and vernacular-only phonemes have conventional characters by which they are represented in Arabic orthography. Vernacular-only phonemes, in contrast, have no parallel characters in the Arabic alphabet. Notably, the aforementioned categorization is unique to SAV and may vary in other categories. Just the same, all three categories appear in all versions (Maamouri, 1998).

The phonological distance between MSA and SAV suggests that standard phonemes cannot be familiar to children when they begin to acquire reading proficiency in first grade. Accordingly, to gain an initial mastery of reading, youngsters may have to learn not only the orthographic representations of these phonemes but their phonological representations as well. Three factors may make this a complex task: 1) To acquire standard phonemes (such as $ض$-ذ [d-š- $\underline{d}]$ ), learners must construct new phonetic categories that do not exist in young children's phonological systems; 2) Standard phoneme types are identified as "heavy" phonemes that are more strongly accented than other phonemes (such as semble other unmarked phonemes in the system. 3) Both types of phonemes, vernacular and standard, have distinct characters that represent them in the Arabic alphabet. Consequently, inaccurate phonological representation of standard phonemes may render children unable to distinguish between standard and vernacular ones and make it hard for them to associate the various phonemes with the characters that represent them.

Children who speak Arabic as their native language may find phonological coding of standard words in long-term memory difficult and may encounter problems in accuracy and organizing words into categories. This confusion disrupts phonological analysis even in tasks that do not require phonological representation. This finding has crucial implications for the acquisition of reading proficiency in Arabic and for the ways this proficiency is imparted. The results show that the strictly limited and largely passive natural exposure of Arabic-speaking children to the literary language does not suffice to enable them to construct high-quality phonological representations for words in MSA. The construction of stable phonological representations improves the learning of words and facilitates the acquisition of reading proficiency (Perfetti, 2007).

\section{Transfer of language skills between languages}

The issue of linguistic skills transfers from one language to another concerned and still concerns scholars of different linguistic backgrounds. Schiff and Calif (2007) examined the contribution of morphologic awareness for reading acquisition in two alphabetical languages, Hebrew, (L1) which has transparent orthography and English [second language] that has deep orthography, among $5^{\text {th }}$ grade pupils in Israel. The researchers reported that they had fund a strong positive correlation between morphologic awareness and linguistic skills in both Hebrew and English, and that morphologic tasks in Hebrew predicted reading ability in English. 
Analysis of the orthographic and morphologic systems of Arabic and English leads to the deduction that alphabetical languages differ in their morphologic and orthographic transparency measure: the Arabic language has transparent orthography but on the other hand, it is characterized by an opaque morphologic system, while English is an alphabetic language with opaque orthographic system and transparent morphologic system.

These linguistic properties affect the words decoding and identification process. Therefore, it is reasonable to assume that those Arab learners will rely more on phonological processing than on morphologic processing when reading, whereas English learners will rely more on morphologic analysis.

The study of Kahn-Horwitz et al. (2005) yielded similar findings: They found significant connection in morphologic skill in the L1 (Hebrew) and words reading in the SL (English). They also found that morphologic awareness in Hebrew contributed to reading comprehension in English. Bindman's (2004) study revealed similar results, which indicated that morphologic tasks in Hebrew had significant contribution to reading and spelling in English.

These findings were also supported by the findings of Kieffer \& Lesaux (2008) who examined the connection between morphologic awareness and reading comprehension among bilingual Spanish pupils who learn English as second language. The findings of the two years study indicated that the connection between morphologic awareness and reading comprehension was strengthened from 4th grade to 5th grade. It also found a significant connection between awareness of morphological derivation in Spanish and reading comprehension in English.

Deacon and others (2009) examined the influence of morphologic awareness on reading in two languages with deep orthography; English and French. The study had been conducted among bilingual English children learning French as second language. The researchers reported a bi-directional transfer of morphologic skill between the two languages. In other words, morphologic awareness in English was an important predictor for words reading in French, and morphological skills in French predicted words reading in English.

Wang, Ko and Choi (2009) examined the inter-lingual transfer of morphologic skills among bilingual Korean (a language with flat orthography) speaking children who learn English as second language. The study revealed that morphologic awareness predicted words reading and reading comprehension in both languages, Korean and English. In addition, a significant connection was found between morphologic skills in Korean and words reading and reading comprehension in English. On the other hand, morphologic awareness in English had no connection to words reading and reading comprehension in Korean.

Furthermore, the findings of the above-mentioned studies showed unilateral transfer of the morphologic awareness skill from languages with flat orthographies, like Arabic, Hebrew, Spanish Finish and Korean to the English language, but such transfer did not occur from the English language to those languages. 
Ramirez et al. (2010) claimed that in most cases, flat orthographies are characterized by complex morphologic systems, while deep orthographies are characterized by simple morphologic systems. The inter-lingual transfer of the morphologic awareness skill is more likely to occur from complex morphologic system to simple morphologic systems, and less likely to occur from simple morphologic system to complex morphologic systems while the study of Deacon et al. (2009), indicated bi-directional inter-lingual transfer of morphologic awareness skills between English and French. The researchers deduced that when morphologic systems of languages have similar complexity, the transfer of morphologic awareness skills would bilaterally occur.

The study of Kahn-Horwitz et al. (2005), examined linguistic factors in the L1 [Hebrew] that might be contributive to reading comprehension in the SL [English], among Hebrew speaking children who learn English as second language. The findings indicated that linguistic skills such as; phonologic awareness, morphologic awareness and word identification in the L1 were strong predictor to reading comprehension in the second language.

The study of Proctor et al. (2006), revealed similar findings; the study examined the influence of alphabetic linguist knowledge, reading flow, vocabulary size and hearing comprehension in Spanish as L1, were the strongest predictors to reading comprehension in English as second language. However, it is important to point out that these researchers emphasized the important of the teaching factor, which can fulfil an imperative role in bilingual developments and inter-linguistic transfer. The study of Lefranois \& Armand (2003) found that syntax knowledge in the L1 [Spanish], was a strong predictor to acquisition of reading comprehension skills in the SL [French].

Similar results had been received in the study of Van Gelderen et al. (2004), who investigated the linguist components of reading comprehension in Dutch as L1, and their influence on reading comprehension components in the SL [English], among Dutch children. The research findings indicated that the speed of word decoding did not contribute to reading comprehension in both languages, Dutch and English, but on the other hand, the same research found significant positive correlation in both languages in all other reading comprehension components that were examined, such as vocabulary extent, grammar knowledge, and meta-cognitive knowledge. Furthermore, it was found that the strongest contributive component to reading comprehension in Dutch was meta-cognitive knowledge, while the best contributors to reading comprehension in English were two components: meta-cognitive knowledge and vocabulary extent.

In another study conducted by Nassaji and Geva (1999), the findings indicated that the skills of orthographic processing in Persian as L1, significantly contributed to acquisition of reading comprehension skills in the second language, English. Similar findings were received in the study of Wang et al. (2009), which indicated the morphologic awareness in Korean as L1, was a strong predictor to reading comprehension both in the L1 and in English as second lan- 
guage.

Koda and others (2008) investigated the contribution of morphologic awareness to reading comprehension in the English language among bilingual Chinese children, of orthographic logographic background who learn English as second language. The findings revealed that morphologic awareness in the $\mathrm{L} 1$, (Chinese) and well as in, the SL (English) is a strong predictor for reading comprehension in the second language.

Similar finding emerged in a study conducted by Hirai (1999), which examined bilingual Japanese students learning English as second language. The students were tested in reading, hearing comprehension and reading comprehension tasks in both languages, Japanese, which is a logographic language, and English. The research findings indicated transfer of linguistic skills from one language to the other, meaning that student that had low achievements in reading ability, hearing and reading comprehension in the L1 (Japanese) had low achievements in similar tasks in English, while students that had good ability in the skills examined, reached good achievements in the SL (English).

The findings of the studies mentioned above indicate that linguist components like phonological awareness, morphological awareness, orthographic knowledge, syntactic awareness, vocabulary and meta-cognitive knowledge in the L1 contribute to reading comprehension in the second language. These findings provide additional support to Cummings' (1979) interdependence hypothesis.

The study of Wang et al. (2006), the findings indicated that morphologic awareness in English did not contribute to reading comprehension skills in Chinese. A study conducted by Akamatsu (2003), revealed that Chinese and Japanese children of logographic orthographic background presented low-level achievements in words processing, reading and reading comprehension in SL [English], compared to achievements reached by Persian children of alphabetic linguistic background.

Similar findings emerged in the study of Guo and Roehrig (2011), who found that meta-cognitive awareness in SL (English) of bilingual Chinese students does not predict the reading comprehension skill in that language. The researchers explained these findings in the fact that most participants had weak linguistic knowledge in the second language, English, which was under the threshold that enables an inter-lingual transfer of general reading knowledge [meaning awareness of reading strategies] from the L1, Chinese, into English.

One of the major challenges of learning to read in Arabic is the fact that speakers of the language speak different language than the language they write in. The Arabic children speak at home and in the neighborhood is quite different from the written literary Arabic. This linguist phenomenon is called diglossia. Educated Arabs use literary Arabic for reading, writing and speaking in formal events. On the other hand, educated Arabs, like uneducated Arabs, use spoken Arabic in all the basic daily communications; like family conversations, small talk, shopping and entertainment (Abu-Rabia, Share, \& Mansour, 2003; Abu-Rabia \& Taha, 2006). 


\section{Research question}

1) How do Arab and Jewish pupils acquire the Arabic language in bilingual schools, compared to pupils learning in monolingual schools?

\section{Research hypothesis}

1) Arab pupils will be more successful in the acquisition of Arabic compared to their Jewish peers in the bilingual school and compared to Arabic pupils learning in monolingual school.

2) Jewish pupils will be more successful in the acquisition of Arabic compared to their Jewish peers in monolingual schools.

\section{Method}

\section{Participants}

The research sample consisted of Jewish and Arabic pupils from grades 3, 5 \& 6. The research population comprised of randomly selected samples of 30 Arabic pupils and 30 Jewish pupils from each grade level, meaning, an overall sample consisted of 180 participants from bilingual schools. Arabic pupils of similar grades learning in monolingual schools, and Jewish pupils of similar grades attending monolingual schools comprised the control group $(\mathrm{N}=90)$. Achievements of Arabic pupils in Arabic had been compared to achievements in Arabic of Arabic pupils in monolingual schools.

The criteria for participant's selection and fitting had been: Age and grade, similarity of learning materials and residential environment type [rural or urban] the choice of control populations was made according to similarity of socio-economical background.

Tools

1) Identification of pointed words (Abu-Rabia \& Abu-Rahmoun, 2012): A list of 40 words in ascending difficulty order based on the Arabic language learning materials of the participants. The difficulty level is determined according to the length, morphologic complexity and its frequency in the Arabic language. The participants were asked to read aloud, and the scores will relate to accuracy and reading flow.

2) Identification of non-pointed words (Abu-Rabia \& Abu-Rahmoun, 2012): A list of 40 non-diacritical words in ascending difficulty order, based on the Arabic language learning materials of the participants. The difficulty level is determined according to the length, morphologic complexity and its frequency in the Arabic language. The participants were asked to read aloud, and the scores will relate to accuracy and reading flow.

3) Working memory (Abu-Rabia \& Abu-Rahmoun, 2012): Each of the participants is tested separately. The test was based on the version of Siegel and Ryan (1989), translated and modified into Arabic. It is comprised of sentences that each of them is read aloud to the participant without its final word that the participant must complete. The test is composed of four stages. In each stage the number of words, the participant must fill in rises $(2-5)$. They were permitted to try 3 times in each stage. They had to fill in the missing word and later to re- 
peat all the words.

Examples for sentences: "When we don't see well, we put on..." “The colors of the Israeli flag are blue and..." the participants were asked to repeat the words he filled in according to the order of the sentences. In this case, glasses and white.

4) Orthography (Assadi, 2012). The test comprised of 17 lines of words, 6 words in a line. Some words are written correctly and others are not. The participants were to choose the words written correctly according to the spelling and grammatical rules of Arabic and to identify words written wrongly and mark them by a diagonal line.

5) Phonological awareness (Assadi, 2012)

a) Phoneme Analysis: This test examines the pupil's ability to divide words into phonemes. The tester says a target word, the individual tested has to repeat the word he/she hears and then to take it apart for phonemes. This test contains 18 words.

b) Synthesis: A test of blending phonemes into words: This test examines the participant's ability to merge phonemes into words. The individual tested is asked to listen to phonemes and attach then into a word. This test contains eight items in ascending difficulty level. From words containing three phonemes to words containing six phonemes, two words in each level.

c) Phoneme Omission: In this test, the participant is asked to omit a beginning, middle or end phoneme from a word he/she hears. The participant listens to the phoneme omitted separately and is asked to utter it and then utter the reminding sequence.

6) Morphology

a) Derivative morphology in productive level (Abu-Rabia \& Abu-Rahmoun, 2012). The test contains 40 roots and the individual tested has to derive as many words as he can from each of these roots. The roots are presented in ascending difficulty grade, from the easy and frequent to the difficult and less frequent.

b) Morphological judgment (Taha, 2013). In this test the individual tested is presented with pairs of words and he must determine respond quickly by saying "Yes" if both words derive from the same root and saying "No" if they have different root.

7) Spelling (Assadi, 2012): The participant is presented with a list of words dictated by the tester, in an ascending level of difficulty. The list is composed of words taken from the pupil's textbooks in Arabic. The list of words is of the same level of the list of words intended for reading aloud, punctuality and fluency, and includes 24 words.

8) Reading Comprehension (Assadi, 2012): This test is composed of two texts (one fully pointed, the second unpointed) and multiple-choice questions relating to them. The texts are taken from the subject's textbooks. Each text is about one page long with 14 questions about it. The topics of the texts are related to the subject's environment: "The Bees", "Milk and Dairy".

9) Syntactic judgment (Assadi, 2012): Participants were presented with 31 
sentences, some of them are syntactically correct and some are not. Participants were required to determine the syntactically correct and incorrect sentences.

10) Pseudoword decoding (Taha, 2013): The test examines the participants' ability to accurately code and decipher pseudowords. Participants were required to read aloud as quickly and as accurately as possible a list of 32 pseudowords. The task measures the ratio of precision (correct answers out of the total assignments).

\section{Results}

\section{Development of skills in Arabic}

Pupils' skills development in the Arabic language was examined by two different comparisons; first, it was checked whether the linguist skills in Arabic of Arabic pupils learning in bilingual school differ from those of Arabic pupils learning in monolingual schools, and the second was checking whether the Arabic language skills of these two groups differ from those of the Jewish pupils learning in bilingual schools that for them, Arabic is a SL.

These issues were examined by unilateral difference analysis (ANOVA) to compare linguistic skills of pupils from different grades/age groups, as specified in the following. Examination of differences between different research groups was performed by means of Post Hoc analysis according to Tuckey. The groups examined had been Arabic pupils from monolingual schools, Arabic pupils from the bilingual schools and Jewish pupils from bilingual schools. Arabic is the mother tang [L1] for the first two groups, and for the third group, the Jewish pupils, it is second/FL. The results of the analysis are presented in Table 1.

\section{Analysis of Arabic skills in $3^{\text {rd }}$ grade}

Generally, the results of $3^{\text {rd }}$ grade revealed that there were no significant differences between Arab pupils learning in bilingual schools, Jewish pupils learning in bilingual schools, and Arab pupils learning in monolingual schools. Nevertheless, it was found that there are some differences among the groups in reading pointed words, $(\mathrm{F}(2.87)=4.82, p<0.1)$ : Skills of the Arab pupils learning in bilingual schools were higher than those of Arab pupils learning in monolingual schools (Table 1).

Significant differences between the research groups were also found in reading non-pointed words [F (2.87) 12.20, $p<0.1]$. In this case, it was found that the skills of the Arab pupils learning in monolingual school are significantly lower from those of Arab pupils learning in bilingual schools, and the skills level of the Jewish pupils learning in bilingual school (Table 1).

Similar findings were found in reading non-words without diacritics (F (2.87) $=19.85, p<0.1)$. The results of the Arab speaking pupils learning in monolingual schools were significantly lower compared to those of Arab pupils learning in bilingual schools and from the skills level of Jewish pupils learning in bilingual schools. In this context, no differences were found between Arab pupils and Jewish pupils learning in bilingual school (Table 1). 
Table 1. Comparison of Arabic language skill (\%) by grade, school type and sector.

\begin{tabular}{|c|c|c|c|c|c|c|c|c|c|c|c|c|}
\hline \multirow{3}{*}{$\begin{array}{l}\text { Linguistic } \\
\text { skills }\end{array}$} & \multicolumn{4}{|c|}{$3^{\text {rd }}$ grade } & \multicolumn{4}{|c|}{$5^{\text {th }}$ grade } & \multicolumn{4}{|c|}{$6^{\text {th }}$ grade } \\
\hline & \multicolumn{2}{|c|}{ Bilingual } & \multirow{2}{*}{$\frac{\text { monolingual }}{\text { Arab }}$} & \multirow{2}{*}{ - } & \multicolumn{2}{|c|}{ Bilingual } & \multirow{2}{*}{$\frac{\text { monolingual }}{\text { Arab }}$} & \multirow{2}{*}{$\mathrm{F}$} & \multicolumn{2}{|c|}{ Bilingual } & \multirow{2}{*}{$\frac{\text { monolingual }}{\text { Arab }}$} & \multirow{2}{*}{$\mathrm{F}$} \\
\hline & Jewish & Arab & & & Jewish & Arab & & & Jewish & Arab & & \\
\hline $\begin{array}{c}\text { Identification: } \\
\text { Diacritical } \\
\text { Words }\end{array}$ & $\begin{array}{c}36.57_{1,2} \\
(8.87)\end{array}$ & $\begin{array}{l}38.23_{1} \\
(8.14)\end{array}$ & $\begin{array}{l}31.87_{2} \\
(7.65)\end{array}$ & $4.82^{\star *}$ & $\begin{array}{l}73.37_{1} \\
(5.30)\end{array}$ & $\begin{array}{l}73.77_{1} \\
(5.47)\end{array}$ & $\begin{array}{l}67.97_{2} \\
(6.48)\end{array}$ & $9.44^{* *}$ & $\begin{array}{l}79.03_{1} \\
(3.58)\end{array}$ & $\begin{array}{l}78.53_{1} \\
(3.29)\end{array}$ & $\begin{array}{l}73.10_{2} \\
(5.77)\end{array}$ & $17.14^{* *, \mathrm{a}}$ \\
\hline $\begin{array}{c}\text { Identification: } \\
\text { Non-Diacritical } \\
\text { Words }\end{array}$ & $\begin{array}{l}34.23_{1} \\
(8.68)\end{array}$ & $\begin{array}{l}34.70_{1} \\
(8.95)\end{array}$ & $\begin{array}{l}25.67_{2} \\
(5.94)\end{array}$ & $12.20^{\star *}$ & $\begin{array}{l}62.70_{2} \\
(6.03)\end{array}$ & $\begin{array}{l}66.53_{1} \\
(4.80)\end{array}$ & $\begin{array}{l}59.77_{2} \\
(6.58)\end{array}$ & $10.09^{\star *}$ & $\begin{array}{l}71.53_{1} \\
(3.87)\end{array}$ & $\begin{array}{l}70.50_{1} \\
(3.48)\end{array}$ & $\begin{array}{l}66.77_{2} \\
(5.96)\end{array}$ & $9.05^{\star \star, a}$ \\
\hline Pseudo-Word & $\begin{array}{l}25.20_{1} \\
(5.74)\end{array}$ & $\begin{array}{l}27.40_{1} \\
(6.78)\end{array}$ & $\begin{array}{l}18.37_{2} \\
(4.66)\end{array}$ & $19.85^{\star *}$ & $\begin{array}{l}43.83_{2} \\
(10.40)\end{array}$ & $\begin{array}{l}52.47_{1} \\
(9.75)\end{array}$ & $\begin{array}{l}46.13_{2} \\
(10.16)\end{array}$ & $5.87^{* *}$ & $\begin{array}{l}57.20_{1} \\
(8.52)\end{array}$ & $\begin{array}{l}56.87_{2} \\
(8.76)\end{array}$ & $\begin{array}{l}49.63_{2} \\
(7.11)\end{array}$ & $8.23^{* *}$ \\
\hline $\begin{array}{c}\text { Phon. } \\
\text { Awareness: } \\
\text { Analysis }\end{array}$ & $(7.23)$ & $\begin{array}{l}34.37 \\
(7.15)\end{array}$ & $\begin{array}{l}31.10 \\
(6.40)\end{array}$ & 1.95 & $\begin{array}{l}62.00_{1} \\
(9.09)\end{array}$ & $\begin{array}{l}63.67_{1} \\
(11.70)\end{array}$ & $\begin{array}{l}54.07_{2} \\
(13.34)\end{array}$ & $5.96^{* *, a}$ & $\begin{array}{l}74.73_{1} \\
(5.60)\end{array}$ & $\begin{array}{l}73.47_{1} \\
(6.31)\end{array}$ & $\begin{array}{l}66.33_{2} \\
(5.31)\end{array}$ & $18.57^{\star *}$ \\
\hline $\begin{array}{c}\text { Phon. } \\
\text { Awareness: } \\
\text { Synthesis }\end{array}$ & $\begin{array}{l}31.30 \\
(5.76)\end{array}$ & $\begin{array}{l}32.47 \\
(5.21)\end{array}$ & $\begin{array}{l}29.53 \\
(5.20)\end{array}$ & 2.25 & $\begin{array}{l}60.87 \\
(8.80)\end{array}$ & $\begin{array}{c}61.97 \\
(11.01)\end{array}$ & $\begin{array}{c}54.53 \\
(12.41)\end{array}$ & $4.11^{\mathrm{a}}$ & $\begin{array}{l}73.67_{1} \\
(5.86)\end{array}$ & $\begin{array}{l}71.87_{1} \\
(6.72)\end{array}$ & $\begin{array}{l}65.70_{2} \\
(5.91)\end{array}$ & $13.73^{\star *}$ \\
\hline $\begin{array}{c}\text { Phon. } \\
\text { Awareness: } \\
\text { Omitting }\end{array}$ & $\begin{array}{l}30.03 \\
(4.70)\end{array}$ & $\begin{array}{l}32.60 \\
(5.35)\end{array}$ & $\begin{array}{l}29.67 \\
(5.59)\end{array}$ & 2.81 & $\begin{array}{l}61.40 \\
(9.16)\end{array}$ & $\begin{array}{c}63.60 \\
(10.80)\end{array}$ & $\begin{array}{c}55.87 \\
(11.36)\end{array}$ & $4.34^{\star}$ & $\begin{array}{l}73.03_{1} \\
(4.93)\end{array}$ & $\begin{array}{l}70.93_{1} \\
(6.43)\end{array}$ & $\begin{array}{l}65.70_{2} \\
(4.98)\end{array}$ & $14.20^{\star \star}$ \\
\hline Orthography & $\begin{array}{l}35.67 \\
(9.37)\end{array}$ & $\begin{array}{c}37.30 \\
(10.71)\end{array}$ & $\begin{array}{l}34.07 \\
(9.26)\end{array}$ & 0.82 & $\begin{array}{l}69.23 \\
(6.77)\end{array}$ & $\begin{array}{l}72.70 \\
(5.22)\end{array}$ & $\begin{array}{l}64.33 \\
(6.36)\end{array}$ & $14.02^{\star *}$ & $\begin{array}{l}75.20_{1} \\
(5.98)\end{array}$ & $\begin{array}{l}74.83_{1} \\
(6.59)\end{array}$ & $\begin{array}{l}70.30_{2} \\
(4.94)\end{array}$ & $6.47^{\star *}$ \\
\hline Morphology 1 & $\begin{array}{l}28.60 \\
(8.34)\end{array}$ & $\begin{array}{l}30.20 \\
(8.48)\end{array}$ & $\begin{array}{l}26.17 \\
(7.89)\end{array}$ & 1.82 & $\begin{array}{r}66.10 \\
(10.89)\end{array}$ & $\begin{array}{l}69.23 \\
(8.85)\end{array}$ & $\begin{array}{l}59.80 \\
(8.80)\end{array}$ & $7.57^{* *}$ & $\begin{array}{l}74.80_{1} \\
(7.50)\end{array}$ & $\begin{array}{l}74.30_{1} \\
(7.14)\end{array}$ & $\begin{array}{l}66.83_{2} \\
(8.43)\end{array}$ & $10.05^{\star \star}$ \\
\hline Morphology 2 & $\begin{array}{l}28.60 \\
(8.17)\end{array}$ & $\begin{array}{l}29.90 \\
(8.60)\end{array}$ & $\begin{array}{l}26.37 \\
(7.74)\end{array}$ & 1.43 & $\begin{array}{c}65.73 \\
(10.75)\end{array}$ & $\begin{array}{c}66.47 \\
(14.74)\end{array}$ & $\begin{array}{c}59.37 \\
(10.17)\end{array}$ & 3.16 & $\begin{array}{l}73.67_{1} \\
(8.41)\end{array}$ & $\begin{array}{l}73.77_{1} \\
(8.29)\end{array}$ & $\begin{array}{l}67.27_{2} \\
(7.97)\end{array}$ & $6.15^{\star *}$ \\
\hline $\begin{array}{l}\text { Syntax } \\
\text { Judgment }\end{array}$ & $\begin{array}{c}37.83_{1,2} \\
(6.44)\end{array}$ & $\begin{array}{l}39.57_{1} \\
(7.34)\end{array}$ & $\begin{array}{l}34.23_{2} \\
(7.93)\end{array}$ & $4.21^{\star}$ & $\begin{array}{l}68.23 \\
(6.00)\end{array}$ & $\begin{array}{l}70.13 \\
(6.60)\end{array}$ & $\begin{array}{l}63.93 \\
(7.18)\end{array}$ & $6.93^{* *}$ & $\begin{array}{l}74.27_{1} \\
(5.13)\end{array}$ & $\begin{array}{l}72.27_{1} \\
(5.75)\end{array}$ & $\begin{array}{l}65.70_{2} \\
(5.31)\end{array}$ & $20.65^{\star *}$ \\
\hline $\begin{array}{l}\text { Working } \\
\text { Memory }\end{array}$ & $\begin{array}{l}34.83 \\
(7.14)\end{array}$ & $\begin{array}{l}36.47 \\
(7.75)\end{array}$ & $\begin{array}{l}32.60 \\
(7.68)\end{array}$ & 1.99 & $\begin{array}{l}56.20 \\
(6.16)\end{array}$ & $\begin{array}{l}57.60 \\
(6.00)\end{array}$ & $\begin{array}{l}52.27 \\
(5.38)\end{array}$ & $6.69^{* *}$ & $\begin{array}{l}64.87 \\
(6.04)\end{array}$ & $\begin{array}{l}65.53 \\
(6.21)\end{array}$ & $\begin{array}{l}66.00 \\
(5.64)\end{array}$ & 0.27 \\
\hline Spelling & $\begin{array}{l}25.30 \\
(5.00)\end{array}$ & $\begin{array}{l}25.93 \\
(4.81)\end{array}$ & $\begin{array}{l}23.13 \\
(4.97)\end{array}$ & 2.66 & $\begin{array}{l}58.87 \\
(6.78)\end{array}$ & $\begin{array}{l}60.07 \\
(5.56)\end{array}$ & $\begin{array}{l}54.73 \\
(5.72)\end{array}$ & $6.43^{\star *}$ & $\begin{array}{l}69.60 \\
(8.24)\end{array}$ & $\begin{array}{l}68.17 \\
(8.17)\end{array}$ & $\begin{array}{l}64.63 \\
(7.91)\end{array}$ & 2.98 \\
\hline $\begin{array}{c}\text { Syntax } \\
\text { Recognition }\end{array}$ & $\begin{array}{l}28.77 \\
(6.77)\end{array}$ & $\begin{array}{l}29.93 \\
(7.04)\end{array}$ & 26.23 & 2.37 & $\begin{array}{l}67.87 \\
(5.67)\end{array}$ & $\begin{array}{l}70.00 \\
(6.93)\end{array}$ & $\begin{array}{l}63.33 \\
(7.66)\end{array}$ & $7.51^{* *}$ & $\begin{array}{l}76.87_{1} \\
(4.67)\end{array}$ & $\begin{array}{l}75.30_{1} \\
(5.53)\end{array}$ & $\begin{array}{l}70.00_{2} \\
(5.21)\end{array}$ & $14.63^{\star *}$ \\
\hline $\begin{array}{c}\text { Reading } \\
\text { Comprehension }\end{array}$ & $\begin{array}{l}39.23 \\
(8.19)\end{array}$ & $\begin{array}{c}42.87 \\
(10.15)\end{array}$ & $\begin{array}{l}38.43 \\
(9.20)\end{array}$ & 1.97 & $\begin{array}{l}73.97 \\
(5.39)\end{array}$ & $\begin{array}{l}76.33 \\
(5.84)\end{array}$ & $\begin{array}{l}64.37 \\
(5.83)\end{array}$ & $37.16^{\star *}$ & $\begin{array}{l}81.93_{1} \\
(4.38)\end{array}$ & $\begin{array}{l}80.40_{1} \\
(4.64)\end{array}$ & $\begin{array}{l}75.83_{2} \\
(4.98)\end{array}$ & $13.84^{\star *}$ \\
\hline
\end{tabular}

Notes: $-^{\mathrm{a}}$ significant Levine test; $-_{1,2,3}$ findings in the same line of different numeration found significantly different from each other $[p<0.05]$ in Post Hoc tests; ${ }^{* *} p<0.01,{ }^{*} p<0.05$. 
Furthermore, significant differences between groups were also found in syntactic judgement $(\mathrm{F}(2.87)=4.21, p<0.1)$. Arab pupils learning in bilingual schools achieved higher scores than those of Arab pupils learning in monolingual schools. In this case, no differences were found between the skills of these two groups and those of the Jewish pupils learning in bilingual schools (See Table 1).

Furthermore, the results of the Jewish pupils learning in monolingual schools were either similar or significantly lower compare to their peers in the bilingual schools.

\section{Analysis of Arabic skills in $5^{\text {th }}$ grade}

The results of $5^{\text {th }}$ grade indicated significant differences between the research groups in all skills examined, except for morphology 2. The findings indicate no significant differences between Jewish and Arab pupils learning in bilingual schools, however, the linguistic skills of the Arab pupils learning in monolingual schools were considerably lower than those of both Arab and Jewish pupils learning in bilingual schools, regarding identification of diacritical words, phonologic awareness-analysis, orthography, morphology 1, syntactical judgment, working memory, spelling and reading comprehension (Table 1).

As for the phonological awareness-synthesis skill, significant differences were found between the skills of the Arab pupils learning in Bilingual schools and Arab pupils learning in monolingual schools, however to a lesser degree regarding the skills of Jewish pupils learning in bilingual schools (see Table 1).

Similar results were found in the phonological awareness; the differences stem mostly from the skills gap between the Arab pupils learning in bilingual schools and Arab pupils learning in monolingual schools. Unlike the results mentioned above, significant differences were found between the groups regarding the skill of identifying non-diacritical words $(\mathrm{F}(2.87)=10.01, p<0.01)$ to the favor of the Arab pupils learning in bilingual school (Table 1).

Similar findings emerged in reading non pointed words $(\mathrm{F}(2.87)=5.87, p<$ 0.01): The differences in the skills of the Arabic pupils learning in bilingual schools were significantly higher than those of the Jewish pupils learning in bilingual schools and from Arabic pupils learning in monolingual schools. The skill's difference found between the Jewish pupils learning in bilingual schools and Arab pupils learning in monolingual school was insignificant (Table 1).

Furthermore, the results of the Jewish pupils learning in monolingual schools were either similar or significantly lower compare to their peers in the bilingual schools.

\section{Analysis of Arabic skills in $6^{\text {th }}$ grade}

The results of 6 th grade pupils indicated significant differences between the research groups in all skills examined, except for working memory and spelling. The findings indicate that the differences between Jewish and Arab pupils learning in bilingual school are quite insignificant while the skills of the Arab pupils learning in monolingual schools were significantly compared to both 
Jewish and Arab pupils learning in bilingual schools (see Table 1).

In sum, there are no significant differences between pupils' groups in the $3^{\text {rd }}$ grade, particularly about Arab pupils learning in bilingual schools and Arabic pupils learning in monolingual schools.

In the context of identifying non-pointed words, the skills of the Arab pupils learning in monolingual schools were lower compared to those of pupils [both Jewish and Arabic] Learning in bilingual schools. The skills of identification of non-pointed words and syntactical judgement of Arab pupils learning in monolingual schools were lower than those of the Arab pupils learning in bilingual school.

Unlike the findings regarding $3^{\text {rd }}$ grade, finding regarding the higher grades indicate that the skills in the Arabic language of Arab pupils learning in monolingual schools are lower than the skills of the Jewish pupils learning in bilingual schools, that for them, Arabic is foreign [second] language. Furthermore, regarding pupils of the higher grades, it was found that the skills of the Jewish pupils learning in bilingual school were similar to those of Arabic pupils in such schools.

\section{Discussion}

The findings indicated that Arab pupils learning in bilingual school have a significant advantage in reading diacritical words compared to their peers learning in monolingual schools. Similar results were achieved by Jewish pupils learning in bilingual schools, compared to Arab pupils learning in monolingual schools. Namely, pupils learning in bilingual schools, Arabs and Jews, revealed superior reading accuracy in reading diacritical words in Arabic compared to their Arab peers learning in monolingual schools. It is important to point out that Arab and Jewish pupils attending bilingual schools gained similar scores.

In addition, the superiority of the pupils learning in bilingual schools, Arabs and Jews, in the reading of non-diacritical words stood out. Both groups in the bilingual school shown superiority compared to the same task performed by Arabic pupils learning in monolingual schools and the differences found between the Jewish pupils and the Arabic pupils in the bilingual schools were insignificant.

Similar results were found on reading diacritical words and syntactical judgment. The achievements of both Arab and Jewish pupils learning in bilingual schools were better than those of the Arab pupils learning in monolingual schools, and there were no significant gaps between the achievements of the Arab and Jewish pupils learning in bilingual schools.

These results strengthen the importance of phonologic awareness in reading process, the ability of words' decoding and the ability to use phonetic code. The ability to cope with diacritical and non-diacritical words is a result of reading training and exercising, which enables transfer of phonologic skills between Hebrew and Arabic, which strengthens the meta-linguistics of the learners and brings them to a higher level of correct coping. The results indicate that Arab 
and Jewish pupils learning in bilingual schools shown higher linguistic ability than their peers in the monolingual schools do. Thus, the learning of more than one language at tender age strengthens reading skills, in this case, the phonology, diacritical and non-diacritical words.

Our results are supported by the findings of Durgunoglu, Nagy and Hancin-Bhatt (1993), in a study that examined first grade Spanish speaking pupils who learn English the participants were tested in reading skills in both English and Spanish. It was found that the pupils whose performance was better in phonologic awareness in Spanish, read better words and pseudo words in English as SL compared to pupils whose performances in phonologic tasks in Spanish were poor (Durgunoglu, 1998; Cisero \& Royer, 1995).

The results of the current study are compatible with the results of Abu-Rabia and Siegel (2002) who compared bilingual pupils speaking Arabic and English with English speaking monolingual pupils and found that the learning and preserving Arabic did not come at the expense of English language acquisition.

Furthermore, when they compared in the same study (Abu-Rabia \& Siegel, 2002) Arabic dyslectic pupils with English speaking dyslectic pupils, in tasks in English, The Arab bilingual dyslectic revealed similar abilities to those of monolingual dyslectic in most tasks, but the bilingual dyslectics revealed superiority in phonologic and spelling tasks, while monolingual dyslectics revealed superiority only in the syntax task.

The main conclusion was that the bilingual dyslexic improved considerably in Arabic and obtained an additional language, English and the preserving Arabic was not in any way at the expense of acquiring a new language. This finding indicates a skill transfer of from one language to the other that occurs in specific skills, such as morphological awareness and phonological processing.

The result, indicating that bilingual pupils, Arabs and Jews, received better abilities regarding Arabic than their Arab peers learning in monolingual schools, which supports the idea of the advantages in providing bilingual educations from early age for both Jews and Arabs in Israel.

The results of the current study also support and encourage the studies of Seymour et al. (2003), Defior et al. (2002), Wimmer \& Goswami (1994) and others, who examined reading the development of children in English, compared to 13 other European languages. The findings of indicated that reading accuracy and speed in consistent orthographic languages like German, Spanish and Italian were higher compared to script systems characterized by low consistency level, like English.

This finding supports the current study in which the pupils were examined in Arabic a Semitic language with a similar orthography like Hebrew, which become consistent when the script is diacritic, since they are both alphabetic script system that when the orthographies vowelized, have direct connection between letter and sound.

It is important to point out that many studies have indicated that phonological awareness is a strong predictor of reading acquisition, regardless of consis- 
tency measure (Coltheart, 2004).

The results of this study also support the result of a study conducted by Saiegh-Haddad and Geva (2008) who examined the contribution of phonological awareness to reading acquisition in two alphabetic languages, English (L1) and Arabic (second language), among bilingual children in Canada. They reported strong positive compatibility between phonological awareness in English and in Arabic. Phonological awareness in English proved to be a strong predictor in reading regular words and pseudo words in both languages, English and Arabic.

Identical results were received in the study of Wade-Woolley \& Geva (2000) who examined phonological skills in English and Hebrew among bilingual children and found that phonological awareness predicted reading in both languages.

Based on these results, the researchers proposed that alphabetic languages contain some universal phonological principles unconnected to any specific language, which can be transferred between languages (Bialystok, Craik, \& Luk, 2012).

To sum it all up, the current study found that children learning two Semitic languages, Arabic and Hebrew, developed academic abilities, and based on meta-linguistic abilities that enable successful coping with reading in Arabic compared to less successful coping presented by pupils learning in monolingual school.

The current study shows that regarding skills pertaining to Arabic, bilingual participants of all age groups presented higher meta-linguistic abilities in Arabic (L1 of Arabic pupils and SL to Jewish pupils) compared to their Arabic peers learning in monolingual schools. Meaning that bilingualism has positive influence on the meta-linguistic skills of both Arabic and Jewish pupils (Bialystok, Majumder, \& Martin, 2003).

\section{Limitations of the Study and Future Studies}

The current study examined linguistic aspects of pupils in various age groups at a certain point in time, in an attempt to learn and reach conclusions regarding the development of pupils' Arabic skills. However, the best way to learn about developmental changes in a more reliable and comprehensive way would be to conduct a long-term study and check the pupils in different continuing time points. In addition, it is important to conduct in-class observations to learn on bilingual schools' climate and in-class dynamics, an issue that was not been looked at in the current study. This point was not examined regardless of the problematic Arab-Israeli social context.

Continuing studies should include interviews with Jewish and Arab pupils, parents, teachers and principals to learn about the atmosphere and the support of the learners' environment. Another important point that had not been examined is the question: What happens next? Why there are no bilingual high schools in Israel? Why pupils, both Jews and Arabs, do not continue and do not 
seek continuation of bilingual education?

Learning an additional language is a political decision, thus it is important to understand how regular learning of "conflict languages" was possible in the difficult Israeli social political climate in these bilingual schools. On paper, Arabic is an official language in the state of Israel, but in the intolerant political climate in Israel, there is not enough public support in the Jewish majority sector to learn Arabic, and as surveys revealed, many Jewish youth possess negative attitudes towards the learning of Arabic. These interesting and important issues may challenge future studies.

\section{Conflicts of Interest}

The authors declare no conflicts of interest regarding the publication of this paper.

\section{References}

Abu-Rabia, S. (1995). Learning to Read in Arabic: Reading, Syntactic, Orthographic and Working Memory Skills in Normally Achieving and Poor Arabic Readers. Reading Psychology: An International Quarterly, 16, 351-394. https://doi.org/10.1080/0270271950160401

Abu-Rabia, S. (1997). Reading in Arabic Orthography: The Effect of Vowels and Context on Reading Accuracy of Poor and Skilled Native Arabic Readers. Reading and Writing. An Interdisciplinary Journal, 9, 65-78. https://doi.org/10.1023/A:1007962408827

Abu-Rabia, S. (2001). The Role of Vowels in Reading Semitic Scripts: Data from Arabic and Hebrew. Reading and Writing: An Interdisciplinary Journal, 14, 39-59. https://doi.org/10.1023/A:1008147606320

Abu-Rabia, S. (2002). Reading in a Root-Based-Morphology Language: The Case of Arabic. Journal of Research in Reading, 25, 299-309. https://doi.org/10.1111/1467-9817.00177

Abu-Rabia, S. (2003). The Influence of Working Memory on Reading and Creative Writing Processes in a Second Language. Educational Psychology, 23, 209-222. https://doi.org/10.1080/01443410303227

Abu-Rabia, S., \& Abu-Rahmoun, N. (2012). The Role of Phonology and Morphology in the Development of Basic Reading Skills of Dyslexic and Normal Native Arabic Readers. Creative Education, 3, 1259. https://doi.org/10.4236/ce.2012.37185

Abu-Rabia, S., \& Siegel, L. S. (2002). Reading, Syntactic, Orthographic, and Working Memory Skills of Bilingual Arabic-English Speaking Canadian SL Reading in Text. Language Learning, 53, 207-231.

Abu-Rabia, S., \& Taha, H. (2006). Phonological Errors Predominate in Arabic Spelling across Grades 1-9. Journal of Psycholinguistic Research, 35, Article No. 167. https://doi.org/10.1007/s10936-005-9010-7

Abu-Rabia, S., \& Taha, H. (2013). Reading in Arabic Orthography: Characteristics, Research Findings, and Assessment. In Handbook of Orthography and Literacy (pp. 335-352). Routledge.

Abu-Rabia, S., \& Awwad, J. (2004). Morphological Structures in Visual Word Recognition: The Case of Arabic. Journal of Research in Reading, 27, 321-336.

https://doi.org/10.1111/j.1467-9817.2004.00235.x

Abu-Rabia, S., Share, D., \& Mansour, M. (2003). Word Recognition and Basic Cognitive 
Processes among Reading-Disabled and Normal Readers in Arabic. Reading and Writing: An Interdisciplinary Journal, 16, 423-442. https://doi.org/10.1023/A:1024237415143

Adams, M. J. (1994). Beginning to Read: Thinking and Learning about Print. MIT Press.

Akamatsu, N. (2003). The Effects of L1 Orthographic Features on SL Reading in Text. Language Learning, 53, 207-231. https://doi.org/10.1111/1467-9922.00216

Alderson, J. C., \& Urquhart, A. H. (1988). This Test Is Unfair: I'm Not an Economist. In P. Carrell, J. Devine, \& D. Eskey (Eds.), Interactive Approaches to Second Language Reading (Cambridge Applied Linguistics, pp. 168-182). Cambridge University Press. https://doi.org/10.1017/CBO9781139524513.018

Al-Tamimi, Y., \& Rabab'Ah, G. (2007). The Relationship between Phonological Awareness and Word Reading. Poznan Studies in Contemporary Linguistics, 43, 5-21. https://doi.org/10.2478/v10010-007-0011-6

Assadi, A. (2012). The Influence of Cognitive and Lingual Functioning on the Development of Reading in Arabic during Grades 1-6. Unpublished Master's Thesis, University of Haifa.

Asaad, H., \& Eviatar, Z. (2014). Learning to Read in Arabic: The Long and Winding Road. Reading and Writing, 27, 649-664. https://doi.org/10.1007/s11145-013-9469-9

Ben-Rafael, E., \& Brosh, H. (1991). Aerobiological Study of Language Diffusion: The Obstacles to Arabic Teaching in the Israeli School. Language Planning and Language Problems, 15, 1-23. https://doi.org/10.1075/lplp.15.1.01ben

Bialystok, E., Craik, F. I., \& Luk, G. (2012). Bilingualism: Consequences for Mind and Brain. Trends in Cognitive Sciences, 16, 240-250.

https://doi.org/10.1016/j.tics.2012.03.001

Bialystok, E., Majumder, S., \& Martin, M. M. (2003). Developing Phonological Awareness: Is There a Bilingual Advantage? Applied Psycholinguistics, 24, 27-44.

https://doi.org/10.1017/S014271640300002X

Bindman, M. (2004). Grammatical Awareness across Languages and the Role of Social Context: Evidence from English and Hebrew. In Handbook of Children's Literacy (pp. 691-709). Springer. https://doi.org/10.1007/978-94-017-1731-1_36

Carlisle, J. F. (1995). Morphological Awareness and Early Reading Achievement. In L. B. Feldman (Ed.), Morphological Aspects of Language Processing (pp. 189-209). Erlbaum.

Carlisle, J. F., \& Fleming, J. (2003). Lexical Processing of Morphologically Complex Words in the Elementary Years. Scientific Studies of Reading, 7, 239-253. https://doi.org/10.1207/S1532799XSSR0703_3

Carlisle, J. F., \& Stone, C. A. (2003). The Effects of Morphological Structure on Children's Reading of Derived Words in English. In E. M. H. Assink, \& D. Sandra (Eds.), Reading Complex Words. Neuropsychology and Cognition (Vol. 22, pp. 27-52). Springer. https://doi.org/10.1007/978-1-4757-3720-2_2

Carroll, S. (2000). Input and Evidence: The Raw Material of SL Acquisition. John Benjamin's. https://doi.org/10.1075/lald.25

Casalis, S., \& Louis-Alexandre, M. F. (2000). Morphological Analysis, Phonological Analysis and Learning to Read French: A Longitudinal Study. Reading and Writing, 12, 303-335. https://doi.org/10.1023/A:1008177205648

Champion, A. (1997). Knowledge of Suffixed Words: A Comparison of Reading Disabled and Nondisabled Readers. Annals of Dyslexia, 47, 29-55. https://doi.org/10.1007/s11881-997-0019-5

Chiang, P., \& Rvachew, S. (2007). English-French Bilingual Children's Phonological Aware- 
ness and Vocabulary Skills. Canadian Journal of Applied Linguistics, 10, 293-308.

Chiappe, P., Siegel, L. \& Gottardo, A. (2002). Reading-Related Skills of Kindergartners from Diverse Linguistic Backgrounds. Applied Psycholinguistics, 23, 95-116. https://doi.org/10.1017/S014271640200005X

Chiappe, P., Siegel, L., \& Wade-Woolley, L. (2002). Linguistic Diversity and the Development of Reading Skills: A Longitudinal Study. Scientific Studies of Reading, 6, 369-400. https://doi.org/10.1207/S1532799XSSR0604_04

Cisero, C. A., \& Royer, J. M. (1995). The Development and Cross-Language Transfer of Phonological Awareness. Contemporary Educational Psychology, 20, 275-303. https://doi.org/10.1006/ceps.1995.1018

Coltheart, M. (2004). Are There Lexicons? The Quarterly Journal of Experimental Psychology Section A, 57, 1153-1171. https://doi.org/10.1080/02724980443000007

Cummins, J. (1979). Linguistic Interdependence and the Educational Development of Bilingual Children. Review of Educational Research, 49, 222-251. https://doi.org/10.3102/00346543049002222

Da Fontoura, H. A., \& Siegel, L. S. (1995). Reading, Syntactic, and Working Memory Skills of Bilingual Portuguese-English Canadian Children. Reading and Writing, 7, 139-153. https://doi.org/10.1007/BF01026951

De Jong, P. F., \& Van der Leij, A. (1999). Specific Contributions of Phonological Abilities to Early Reading Acquisition: Results from a Dutch Latent Variable Longitudinal Study. Journal of Educational Psychology, 91, 450-476.

https://doi.org/10.1037/0022-0663.91.3.450

Deacon, S. H., \& Kirby, J. R. (2004). Morphological Awareness: Just "More Phonological"? The Roles of Morphological and Phonological Awareness in Reading Development. Applied Psycholinguistics, 25, 223-238. https://doi.org/10.1017/S0142716404001110

Deacon, S. H., Wade-Woolley, L., \& Kirby, J. R. (2009). Flexibility in Young Second-Language Learners: Examining the Language Specificity of Orthographic Processing. Journal of Research in Reading, 32, 215-229. https://doi.org/10.1111/j.1467-9817.2009.01392.x

Defior, S., Martos, F., \& Cary, L. (2002). Differences in Reading Acquisition Development in Two Shallow Orthographies: Portuguese and Spanish. Applied Psycholinguistics, 23, 135-148. https://doi.org/10.1017/S0142716402000073

Durgunoglu, A. Y. (2002). Cross-Linguistic Transfer in Literacy Development and Implications for Language Learners. Annals of Dyslexia, 52, 189-204. https://doi.org/10.1007/s11881-002-0012-y

Durgunoglu, A. Y. (1998). Language and Literacy Development in Spanish and English: The U.S.A. Context. In A. Y. Durgunoglu, \& L. Verhoeven (Eds.), Literacy Development in a Multilingual Context: A Cross Cultural Perspective (pp. 135-146). Lawrence Erlbaum.

Durgunoglu, A. Y., Nagy, W. E., \& Hancin-Bhatt, B. J. (1993). Cross-Language Transfer of Phonological Awareness. Journal of Educational Psychology, 85, 453-465. https://doi.org/10.1037/0022-0663.85.3.453

Ehri, L. C. (1992). Reconceptualizing the Development of Sight Word Reading and Its Relationship to Recoding. Lawrence Erlbaum.

Eviatar, Z., \& Ibrahim, R. (2001). Bilingual Is as Bilingual Does: Metalinguistic Abilities of Arabic-Speaking Children. Applied Psycholinguistics, 21, 451-471.

https://doi.org/10.1017/S0142716400004021

Eviatar, Z., Ibrahim, R., \& Ganayim, D. (2004). Orthography and the Hemispheres: Visual 
and Linguistic Aspects of Letter Processing. Neuropsychology, 18, 174-184.

https://doi.org/10.1037/0894-4105.18.1.174

Ferguson, C. A. (1959). Diglossia. Word, 15, 325-340. https://doi.org/10.1080/00437956.1959.11659702

Frost, R. (1994). Prelexical and Postlexical Strategies in Reading: Evidence from a Deep and a Shallow Orthography. Journal of Experimental Psychology-Learning Memory and Cognition, 20, 116-129. https://doi.org/10.1037/0278-7393.20.1.116

Frost, R. (1998). Toward a Strong Phonological Theory of Visual Word Recognition: True Issues and False Trails. Psychological Bulletin, 123, 71-99. https://doi.org/10.1037/0033-2909.123.1.71

Geva, E., \& Siegel, L. (2000). Orthographic and Cognitive Factors in the Concurrent Development of Basic Reading Skills in Two Languages. Reading and Writing: An Interdisciplinary Journal, 12, 1-30. https://doi.org/10.1023/A:1008017710115

Gillon, G. (2002). Follow-Up Study Investigating Benefits of Phonological Awareness Intervention for Children with Spoken Language Impairment. International Journal of Language and Communication Disorders, 37, 381-400. https://doi.org/10.1080/1368282021000007776

Goff, D. A., Pratt, C., \& Ong, B. (2005). The Relations between Children's Reading Comprehension, Working Memory, Language Skills and Components of Reading Decoding in a Normal Sample. Reading and Writing, 18, 583-616.

https://doi.org/10.1007/s11145-004-7109-0

Goswami, U., \& Bryant, P. E. (1990). Phonological Skills and Learning to Read. Lawrence Erlbaum.

Griffin, P., Burns, M. S., \& Snow, C. E. (1998). Preventing Reading Difficulties in Young Children. National Academies Press.

Guo, Y., \& Roehrig, A. D. (2011). Roles of General versus Second Language (L2) Knowledge in L2 Reading Comprehension. Reading in a Foreign Language, 23, 42-64.

Hirai, A. (1999). The Relationship between Listening and Reading Rates of Japanese EFL Learners. The Modern Language Journal, 83, 367-384. https://doi.org/10.1111/0026-7902.00028

Holes, C. (2004). Modern Arabic: Structures, Functions, and Varieties. Georgetown University Press.

Ibrahim, R., \& Aharon-Peretz, J. (2005). Is Literary Arabic a Second Language for Native Arab Speakers?: Evidence from Semantic Priming Study. Journal of Psycholinguistic Research, 34, 51-70. https://doi.org/10.1007/s10936-005-3631-8

Ibrahim, R., \& Eviatar, Z. (2009). Language Status and Hemispheric Involvement in Reading: Evidence from Trilingual Arabic Speakers Tested in Arabic, Hebrew, and English. Neuropsychology, 23, 240-254. https://doi.org/10.1037/a0014193

Ibrahim, R., Eviatar, Z., \& Aharon-Peretz, J. (2007). Metalinguistic Awareness and Reading Performance: A Cross Language Comparison. Journal of Psycholinguistic Research, 36, 297-317. https://doi.org/10.1007/s10936-006-9046-3

Jeon, E. H., \& Yamashita, J. (2014). L2 Reading Comprehension and Its Correlates: A Meta-Analysis. Language Learning, 64, 160-212. https://doi.org/10.1111/lang.12034

Just, M. A., \& Carpenter, P. A. (1987). The Psychology of Reading and Language Comprehension. Allyn \& Bacon.

Kahn-Horwitz, J., Shimron, J., \& Sparks, R. L. (2005). Predicting FL Reading Achievement in Elementary School Students. Reading and Writing, 18, 527-558. 
https://doi.org/10.1007/s11145-005-3179-x

Katz, L., \& Frost, R. (1992). The Reading Process Is Different for Different Orthographies: The Orthographic Depth Hypothesis. Advances in Psychology, 94, 67-84. https://doi.org/10.1016/S0166-4115(08)62789-2

Kieffer, M. J., \& Lesaux, N. K. (2008). The Role of Derivational Morphology in the Reading Comprehension of Spanish-Speaking English Language Learners. Reading and Writing, 21, 783-804. https://doi.org/10.1007/s11145-007-9092-8

Koda, K. (1992). The Effects of Lower-Level Processing Skills on FL Reading Performance: Implications for Instruction. The Modern Language Journal, 76, 502-512. https://doi.org/10.1111/j.1540-4781.1992.tb05400.x

Koda, K. (2005). Insights into Second Language Reading: A Cross-Linguistic Approach. Cambridge University Press. https://doi.org/10.1017/CBO9781139524841

Koda, K., Zhang, Y., \& Yang, C. L. (2008). Literacy Development in Chinese as a Heritage Language. In A. W. He, \& Y. Xiao (Eds.), Chinese as a Heritage Language: Fostering Rooted World Citizenry (pp. 137-149). University of Hawaii Press.

Lefranois, P., \& Armand, F. (2003). The Role of Phonological and Syntactic Awareness in Second-Language Reading: The Case of Spanish-Speaking Learners of French. Reading and Writing, 16, 219-246. https://doi.org/10.1023/A:1022874425314

Leikin, M., Ibrahim, R., \& Eghbaria, H. (2014). The Influence of Diglossia in Arabic on Narrative Ability: Evidence from Analysis of the Linguistic and Narrative Structure of Discourse among Pre-School Children. Reading and Writing, 27, 733-747. https://doi.org/10.1007/s11145-013-9462-3

Lennox, C., \& Siegel, L. S. (1993). Visual and Phonological Spelling Errors in Subtypes of Children with Learning Disabilities. Applied Psycholinguistics, 14, 473-488. https://doi.org/10.1017/S0142716400010705

Maamouri, M. (1998). Language Education and Human Development: Arabic Diglossia and Its Impact on the Quality of Education in the Arab Region. Discussion Paper Prepared for The World Bank, The Mediterranean Development Forum.

Mann, V. A. (1991). Language Problems: A Key to Early Reading Problems. In B. Wong (Ed.), Learning about Learning Disabilities (pp. 129-160). Academic Press. https://doi.org/10.1016/B978-0-12-762530-0.50011-4

Nassaji, H., \& Geva, E. (1999). The Contribution of Phonological and Orthographic Processing Skills to Adult ESL Reading: Evidence from Native Speakers of Farsi. Applied Psycholinguistics, 20, 241-267. https://doi.org/10.1017/S0142716499002040

Nevat, M., Khateb, A., \& Prior, A. (2014). When First Language Is Not First: An Functional Magnetic Resonance Imaging Investigation of the Neural Basis of Diglossia in Arabic. European Journal of Neuroscience, 40, 3387-3395. https://doi.org/10.1111/ejn.12673

Oweini, A., \& Hazoury, K. (2010). Towards a Sight Word List in Arabic. International Review of Education, 56, 457-478. https://doi.org/10.1007/s11159-010-9170-Z

Perfetti, C. A. (2003). The Universal Grammar of Reading. Scientific Studies of Reading, 7, 3-24. https://doi.org/10.1207/S1532799XSSR0701_02

Perfetti, C. (2007). Reading Ability: Lexical Quality to Comprehension. Scientific Studies of Reading, 11, 357-383. https://doi.org/10.1080/10888430701530730

Proctor, C. P., August, D., Carlo, M. S., \& Snow, C. (2006). The Intriguing Role of Spanish Language Vocabulary Knowledge in Predicting English Reading Comprehension. Journal of Educational Psychology, 98, 159. https://doi.org/10.1037/0022-0663.98.1.159

Ramirez, G., Chen, X., Geva, E., \& Kiefer, H. (2010). Morphological Awareness in Span- 
ish-Speaking English Language Learners: Within and Cross-Language Effects on Word Reading. Reading and Writing, 23, 337-358. https://doi.org/10.1007/s11145-009-9203-9

Ravid, D. (2001). Learning to Spell in Hebrew: Phonological and Morphological Factors. Reading and Writing: An Interdisciplinary Journal, 14, 459-485. https://doi.org/10.1023/A:1011192806656

Rayner, K., \& Pollatsek, A. (1989). The Psychology of Reading. Prentice-Hall.

Saiegh-Haddad, E. (2003). Linguistic Distance and Initial Reading Acquisition: The Case of Arabic Diglossia. Applied Psycholinguistics, 24, 431-451. https://doi.org/10.1017/S0142716403000225

Saiegh-Haddad, E. (2004). The Impact of Phonemic and Lexical Distance on the Phonological Analysis of Words and Pseudowords in a Diglossic Context. Applied Psycholinguistics, 25, 495-512. https://doi.org/10.1017/S0142716404001249

Saiegh-Haddad, E. (2007). Linguistic Constraints on Children's Ability to Isolate Phonemes in Arabic. Applied Psycholinguistics, 28, 607-625. https://doi.org/10.1017/S0142716407070336

Saiegh-Haddad, E. (2011). Phonological Processing in Diglossic Arabic: The Role of Linguistic Distance. Perspectives on Arabic Linguistics, XXII, 269-280. https://doi.org/10.1075/cilt.317.12sai

Saiegh-Haddad, E., \& Geva, E. (2008). Morphological Awareness, Phonological Awareness, and Reading in English-Arabic Bilingual Children. Reading and Writing, 21, 481-504. https://doi.org/10.1007/s11145-007-9074-X

Saiegh-Haddad, E., \& Henkin-Roitfarb, R. (2014). The Structure of Arabic Language and Orthography. In Handbook of Arabic Literacy (pp. 3-28). Springer. https://doi.org/10.1007/978-94-017-8545-7_1

Saiegh-Haddad, E., Levin, I., Hende, N., \& Ziv, M. (2011). The Linguistic Affiliation Constraint and Phoneme Recognition in Diglossic Arabic. Journal of Child Language, 38, 297-315. https://doi.org/10.1017/S0305000909990365

Schiff, R., \& Calif, S. (2007). Role of Phonological and Morphological Awareness in L2 Oral Word Reading. Language Learning, 57, 271-298. https://doi.org/10.1111/j.1467-9922.2007.00409.x

Seymour, P. H., Aro, M., Erskine, J. M., \& Collaboration with COST Action A8 Network (2003). Foundation Literacy Acquisition in European Orthographies. British Journal of Psychology, 94, 143-174. https://doi.org/10.1348/000712603321661859

Share, D. L. (1995). Phonological Recoding and Self-Teaching: Sine Qua Non of Reading Acquisition. Cognition, 55, 151-218. https://doi.org/10.1016/0010-0277(94)00645-2

Siegel, L. S., \& Ryan, E. B. (1989). The Development of Working Memory in Normally Achieving and Subtypes of Learning Disabled Children. Child Development, 60, 973-980. https://doi.org/10.2307/1131037

Sparks, R. E. (1995). Need for Ecosystem Management of Large Rivers and Their Floodplains. BioScience, 45, 168-182. https://doi.org/10.2307/1312556

Sparks, R., \& Ganschow, L. (1993). Searching for the Cognitive Locus of Foreign Language Learning Difficulties: Linking First and Second Language Learning. The Modern Language Journal, 77, 289-302. https://doi.org/10.1111/j.1540-4781.1993.tb01974.x

Snow, C. E., \& Sweet, A. P. (Eds.) (2003). Rethinking Reading Comprehension. Guilford Press.

Taha, H. Y. (2013). Reading and Spelling in Arabic: Linguistic and Orthographic Complexity. Theory \& Practice in Language Studies, 3, 721-727.

https://doi.org/10.4304/tpls.3.5.721-727 
Van Gelderen, A., Schoonen, R., De Glopper, K., Hulstijn, J., Simis, A., Snellings, P., \& Stevenson, M. (2004). Linguistic Knowledge, Processing Speed, and Metacognitive Knowledge in First- and Second-Language Reading Comprehension: A Componential Analysis. Journal of Educational Psychology, 96, 19-30. https://doi.org/10.1037/0022-0663.96.1.19

Wade-Woolley, L., \& Geva, E. (2000). Processing Novel Phonemic Contrasts in the Acquisition of L2 Word Reading. Scientific Studies of Reading, 4, 295-311. https://doi.org/10.1207/S1532799XSSR0404_3

Wagner, R. K., \& Barker, T. A. (1994). The Development of Orthographic Processing Ability. In The Varieties of Orthographic Knowledge (pp. 243-276). Springer. https://doi.org/10.1007/978-94-017-3492-9_8

Wang, M., Cheng, C., \& Chen, S. W. (2006). Contribution of Morphological Awareness to Chinese-English Biliteracy Acquisition. Journal of Educational Psychology, 98, 542-553. https://doi.org/10.1037/0022-0663.98.3.542

Wang, M., Ko, I. Y., \& Choi, J. (2009). The Importance of Morphological Awareness in Korean-English Biliteracy Acquisition. Contemporary Educational Psychology, 34, 132-142. https://doi.org/10.1016/j.cedpsych.2008.12.002

Wimmer, H., \& Goswami, U. (1994). The Influence of Orthographic Consistency on Reading Development: Word Recognition in English and German Children. Cognition, 51, 91-103. https://doi.org/10.1016/0010-0277(94)90010-8

Ziegler, J. C., \& Goswami, U. (2005). Reading Acquisition, Developmental Dyslexia, and Skilled Reading across Languages: A Psycholinguistic Grain Size Theory. Psychological Bulletin, 131, 3-29. https://doi.org/10.1037/0033-2909.131.1.3 